\title{
A Seat at the Table: Information Literacy Assessment and Professional Legitimacy
}

\section{Robert Detmering, Samantha McClellan, and Amber Willenborg}

\begin{abstract}
This qualitative study explores academic librarians' perceptions of and experiences with information literacy assessment, focusing primarily on issues of professional identity, agency, and power. Findings from in-depth interviews reveal that instruction librarians view teaching as integral to their professional identity and use assessment to legitimize that identity, both personally and at the institutional level. While this suggests that assessment has the potential to elevate the status of librarians on campus, the interviews also highlight ongoing professional and organizational tensions that hinder assessment efforts and inhibit librarian agency. The authors recommend more transparent communication, among other strategies, to address these challenges.
\end{abstract}

\section{Introduction}

During the last fifteen years, information literacy assessment has become a nearly ubiquitous topic in professional conversations among instruction librarians. Countless presentations and publications, including several entire books on the subject, attest to the enduring popularity of assessment as a central focus of information literacy instruction. ${ }^{1}$ The prevalence of these conversations is not surprising, given the pressing and well-documented need for libraries to demonstrate their impact on student success in response to growing calls for accountability and increasingly competitive budgetary climates in higher education. ${ }^{2}$ As evidenced by a recent systematic review of the literature, despite limited training, instruction librarians appear to exhibit clear dedication to assessment as an essential part of their professional practice and employ a wide variety of methods to assess learning outcomes, sometimes to great success. ${ }^{3}$ Moreover, Devin Savage, Pattie Piotrowski, and Lisa Massengale profile several especially successful assessment projects, emphasizing how such efforts help libraries understand and communicate the value of instruction and other services. ${ }^{4}$ Nevertheless, while the literature suggests that librarians are invested in information literacy assessment and that strong programs have been developed at some institutions, many librarians continue to struggle in this area. Even as assessment has become a significant aspect of the instruction librarian role, librarians generally lack substantial training in assessment and often face barriers at the institutional level by virtue of their dependence on buy-in from teaching faculty and other stakeholders.

\footnotetext{
* Robert Detmering is Information Literacy Coordinator at the University of Louisville; email: robert.detmering@ louisville.edu. Samantha McClellan is Library Instruction Coordinator at California State University, Sacramento; email: s.mcclellan@csus.edu. Amber Willenborg is Online Learning and Digital Media Librarian at the University of Louisville; email: amber.willenborg@louisville.edu. (C2019 Robert Detmering and Samantha McClellan, Attribution-NonCommercial (http://creativecommons.org/licenses/by-nc/4.0/) CC BY-NC.
} 
Indeed, the few studies focusing specifically on information literacy assessment practices report relatively consistent findings regarding the challenges of assessment. An early survey by Megan Oakleaf and Lisa Janicke Hinchliffe shows that a majority of respondents assess information literacy and use the data for instructional improvement. ${ }^{5}$ However, the authors pinpoint multiple challenges for librarians who have had less success with assessment: limited time and resources; lack of assessment training and education; lack of campus support and/or collaboration; and lack of appropriate assessment tools. Likewise, Karen Sobel and Cassidy R. Sugimoto report that most instruction librarians engage in some form of assessment, but they do not spend much time on it; typically do not have professional training in assessment or high confidence with their statistical abilities; and are usually only encouraged, not obligated, to assess instruction, potentially signaling a poor institutional assessment culture. ${ }^{6}$ Additionally, in a more recent survey examining a wide range of instructional activities, Heidi Julien, Melissa Gross, and Don Latham describe librarians' assessment practices as "largely informal," making it difficult to show impact and obtain administrative support. ${ }^{7}$ Their study mostly echoes the assessment challenges identified in prior research, including time constraints, staffing limitations, inadequate training, insufficient administrative support, and problems with faculty buy-in. These factors prevent many librarians from establishing more formal or systematic assessment programs.

Given the apparent centrality of assessment within the instruction librarian role, as well as the aforementioned challenges to developing fully realized assessment programs, it is useful to consider how instruction librarians actually perceive and experience assessment in the context of their daily work. As of this writing, there has been very little research specifically focused on the qualitative experience of information literacy assessment. At the conclusion of their study, Julien, Gross, and Latham call on researchers to begin conducting "in-depth explorations of instructional work through focus groups and interviews." ${ }^{8}$ The present study, then, helps to address this gap in relation to assessment, using extensive semistructured interviews to investigate librarians' perceptions of and experiences with assessment as a particular aspect of instructional practice. In contextualizing librarians' experiences, the study also seeks to elucidate dynamics of professional identity, agency, and status as they pertain to information literacy assessment. For the purposes of this study, the authors considered information literacy assessment broadly as any method, technique, or process used to evaluate the impact or success of information literacy instruction at the class, programmatic, or institutional level. As such, this study does not examine or compare specific methods of assessment, nor does it focus on assessment in other library contexts, such as reference services or collections. The exploratory research questions guiding the study are as follows:

- What role, if any, does information literacy assessment play in instruction librarians' understanding of their professional identity?

- What role, if any, does information literacy assessment play in instruction librarians' sense of agency and status at the institutional level?

- What challenges, if any, do instruction librarians experience in conducting information literacy assessment?

\section{Literature Review}

Beyond the studies cited in the introduction, research on instruction librarians' assessment practices has been somewhat limited, particularly in regard to qualitative experiences. That said, a number of studies investigating the work experiences of instruction librarians provide 
relevant insights. While the present study focuses exclusively on librarians in the United States, this literature review synthesizes research from the United States and Canada as a single body of scholarship because studies from both countries have explored similar issues and identified similar concerns in relation to instruction librarians' experiences. As a whole, this research examines perceptions of the teaching role/identity among instruction librarians as well as the challenges they deal with in carrying out their teaching responsibilities. Several themes emerge across these studies, including instruction librarians' increasingly strong identification with the teaching role over time, the importance of supportive institutional relationships, the challenge of obtaining information literacy buy-in on campus, and the lack of sufficient training for instructional activities, including assessment.

For instance, several studies from the early to mid-2000s present similar findings on the challenges that instruction librarians experience: inadequate staffing and resources for instruction; inconsistent or indeterminate support from teaching faculty and/or administrators; limited confidence in teaching ability and/or knowledge; limited time to dedicate to teaching; and difficulties regarding formal assessment of student learning, despite the prevalence of informal evaluation methods. ${ }^{9}$ While these challenges remain relatively consistent across the studies, the research also suggests that librarians began to embrace the teaching role more fully during this period. Indeed, Heidi Julien finds some divergence in librarians' willingness to take responsibility for teaching various aspects of information literacy, but, five years later, Barry W. Cull reports that librarians express an intense identification with teaching and see it as a "core activity."10

In a later survey of librarians with instructional duties, nearly 80 percent of participants say that instruction is "integral to their professional identity." ${ }^{11}$ Responses to qualitative questions on the same survey show that many librarians enjoy instruction because it allows them to influence student learning, helps them develop positive relationships with patrons, provides professional development opportunities, and increases the visibility of valuable library resources. As in other studies, survey participants also identify challenges related to instruction such as lack of administrative support, faculty buy-in, and appropriate pedagogical training. The authors advocate for improvements in professional training to prepare librarians more effectively for their instructional responsibilities.

In a small qualitative study conducted with six librarians, Scott Walter identifies several specific themes related to the librarian teaching identity. ${ }^{12}$ Walter's participants see teaching as an essential element of their library work, note the value of having strong support from colleagues and administrators in carrying out teaching duties successfully, and point to a number of challenges associated with teaching. These challenges reaffirm many of the findings highlighted in earlier studies: lack of adequate pedagogical training in library schools, the stress of dealing with additional responsibilities that take time away from teaching, and the fact that campus faculty and students often fail to understand the role of librarians in teaching. While not focused on assessment, Walter's research suggests that relationships in the library and on campus influence to a significant degree how librarians perceive and carry out their teaching responsibilities, which may include assessment.

Focusing primarily on the cultural and emotional aspects of instructional work, Celene Seymour reports on an ethnographic study conducted with nine instruction librarians. ${ }^{13}$ Like Walter, Seymour emphasizes the importance of administrative support, both at the library level and the campus level, for building a successful information literacy program. The participants 
in Seymour's research identify inconsistent institutional support for instruction as a particular challenge, coupled with librarians' lack of authority and influence on campus. This kind of organizational environment provokes feelings of frustration and isolation, though librarians also express satisfaction with their role in student learning. Nevertheless, the librarians in this study have limited pedagogical training and have trouble developing systematic assessment methods that demonstrate student success at the institutional level.

Drawing on interviews with academic librarians, Heidi Julien and Jen J.L. Pecoskie also stress the significance of the relationship between librarians and teaching faculty in achieving success with instruction. ${ }^{14}$ Indeed, some participants emphasized faculty relationships more than student learning as a measure of success. Julien and Pecoskie employ sociological theory, including Erving Goffman's work on deference behavior and gift exchange, to demonstrate the unequal power balance between librarians and faculty, with the former dependent on the latter for class time, buy-in, and respect. In light of their findings, Julien and Pecoskie argue that librarians might improve their collaborations with faculty by showing expertise, in part, through measurable learning outcomes. Thus, this research clearly suggests a link between information literacy assessment and campus power relations, a link that the present study seeks to further explicate.

All of these studies examining how librarians think and feel about instruction reflect, to a certain extent, larger professional conversations surrounding the legitimacy of the teaching identity in librarianship and the precarious status of the librarian as teacher. As Lisa O'Connor has shown, the information literacy movement itself is rooted in an "identity crisis" of the 1980s, when educational reforms, financial challenges, and new technologies threatened the traditional status of librarians in the United States. ${ }^{15}$ Starting in this period, information literacy serves as a rationale whereby academic librarians "elevate themselves to equal status with the teaching faculty" and advocate for equal collaborative partnerships in the educational enterprise.${ }^{16}$ However, librarians and teaching faculty often have very different educational backgrounds, experiences, and ranks, which may contribute to lingering uncertainties regarding librarians' status as educators. ${ }^{17}$ Many of the challenges that librarians continue to experience with instruction and assessment in the present, especially those challenges related to campus relationships and support, can be situated within this ongoing evolution of the librarian teaching identity. Tracing the history of key debates over the last two centuries in the United States regarding the role of teaching in librarianship, Emily Drabinski argues that librarians shape their professional identities through a dialogue reflective of particular moments in time and particular claims to power and status. ${ }^{18}$ The importance of assessment in the current time and context warrants further investigation into how librarians perceive assessment and its potential impact on professional identity, agency, and status.

\section{Methods}

The purpose of this qualitative study is to explore academic librarians' perceptions of and experiences with information literacy assessment as a particular aspect of their instructional practice. The authors were interested in highlighting common experiences among instruction librarians; thus, a phenomenological approach was taken to focus on participants' experiences with assessment and the meaning they make from those experiences. ${ }^{19}$ Phenomenology, according to Rick Fought, "focuses on revealing meaning and understanding the essence of a shared experience and works very well with phenomena that do not lend themselves to easy 
quantification." ${ }^{20}$ The concepts under investigation in this study, specifically agency, legitimacy, and status, are difficult to quantify and thus fit the criteria for phenomenological research.

The data reported were collected as part of a larger study on the affective dimensions of information literacy assessment, which was approved by the authors' Institutional Review Board. Twenty-six participants were recruited in person as well as through librarian-focused listservs and social media outlets between April and May 2017. Participants were reviewed prior to participation to confirm that they were both employed as a full-time academic librarian in possession of a Master of Library Science degree and had at least partial job responsibilities in information literacy instruction and assessment.

Twenty-three participants identified as women and three as men, a ratio that closely mirrors the reality of the profession. ${ }^{21}$ Participants ranged in age from 28 to $62(M=40.32$; $S D=11.49$ ) and were from a variety of locations across the United States, including Oregon, Pennsylvania, Kentucky, and Michigan. Twenty-five participants self-identified as either White or Caucasian and one participant self-identified as Black. Participants had been employed as professional librarians for as little as six months and as many as 30 years, with an average total employment length of 11.2 years, and were currently employed by associate's colleges $(n=3)$, baccalaureate colleges $(n=1)$, master's universities/colleges $(n=6)$, and doctoral universities $(n=14)$. Two participants were employed by "other" academic institution types: a four-year comprehensive university and a tri-institutional academic library. Many participants $(n=15)$ indicated that they possessed additional training in information literacy assessment, though there is variety in the degree to which they obtained formal training (such as graduate school courses or webinars). Only three of the 26 participants have been involved in intensive training for information literacy assessment (such as ACRL Immersion Assessment Track or assessment fellowship).

The authors conducted semistructured interviews (see appendix) with each participant in person $(n=2)$ and over the phone $(n=24)$. Participants were prompted to answer questions regarding their experiences with and feelings about information literacy assessment within four separate contexts: personal; within their own library; within the library profession; and within higher education/their own institution. The research questions addressed in this paper focus primarily on respondents' experiences in the personal and institutional contexts. To encourage a wide range of responses and avoid influencing participants' views, participants were not given a specific definition of information literacy assessment but were asked to elaborate on their own views, experiences, and motivations. Participants have offered various kinds of instruction, including one-shot classes, credit classes, and online services, but specific instructional methods were not explored in this study. Likewise, while participants have used a variety of assessment techniques, such as pre-/post-tests, surveys, and minute papers, this study does not focus on particular techniques. A semistructured interview protocol allowed the authors to ask follow-up questions tailored to each participant's answers to gain a deeper and more nuanced understanding of their experiences. ${ }^{22}$ Interviews ranged in duration from 30 minutes to more than 90 minutes, with an average time of one hour.

Interviews were recorded, transcribed, and analyzed for themes related to the authors' research questions. All three authors separately coded transcripts to categorize common themes; they then worked collaboratively to sort relevant quotations into thematic categories. Patterns emerged among participant responses in each category. Respondents are identified with pseudonyms to maintain anonymity. 


\section{Results}

An Emerging Conversation: Assessment, Legitimacy, and the Teaching Identity The first research question examined what role assessment plays in instruction librarians' understanding of their professional identity. As in previous research, respondents consistently acknowledged that their role as instruction librarians corresponded strongly to their professional identities as teachers. Bre explained, "I feel like as librarians, we're educators, and I consider myself to be a teacher." Gwen agreed, stating that she identified as a teacher because information literacy instruction "is the most important thing we do."

In regard to assessment of information literacy instruction, many respondents explained that their professional identity as teachers was inextricably linked to assessment. Sadie stated, "I think teaching and assessment are kind of inseparable and I think assessment shows that I care about teaching"; Cora concurred, saying, "anybody that's going to call themselves [a teacher] has to have some kind of tie to assessment." In other words, assessment confers legitimacy on teaching, which is itself a fundamental component of the instruction librarian identity.

The connection between teaching and assessment was also evident in the responses of several librarians who implicitly connected teaching and assessment with their responsibility as educators to demonstrate student learning. For example, Gwen stated, "I think everybody needs to do [assessment]. Because if you don't, you have no idea if...the time you're taking to teach a class...if it's worth it or not if the students don't learn." Mathilde agreed: "[The role of assessment is to] make sure that students are learning and that the instruction is actually doing the job it's supposed to be doing and that they're meeting the learning outcomes," as did Cora: "I have to have some other way of telling whether students were engaged, whether students have learned anything, what did students already know, what do they know now [after the class]."

Other respondents, including Mathilde and Hannah, explained the benefits of assessment not just for students, but for themselves as educators improving their "personal practice," "changing teaching practices," and having a "growth mindset." Pauline also indicated her enthusiasm for using assessment to improve her teaching, stating, "Maybe I'm at a point where I'm just nuts, because I love it. I love to get feedback, whatever it is" to determine "how well I've done" or "whether there's something I totally screwed up."

It is evident from these discussions that many respondents felt enthusiastic about teaching and excited about the possibility of improving their teaching through assessment. It is also evident that instruction librarians' professional identity as teachers is strongly tied to assessment. What emerged through these conversations about assessment's relationship to librarians' professional identity as teachers was a sense of legitimacy afforded to librarians through assessment. For example, Sadie shared that assessment "legitimizes my professional identity [because assessment is] really wrapped up in my identity as a teacher." Veronica agreed with this sentiment, stating, "I think [doing assessment] helps me feel like I'm more legitimate... I'm trying to accomplish A, and here's how I can show you I've accomplished A."

Initial conversations about legitimacy through assessment revolved around librarians' own conception of themselves and their professional identity as teachers and elicited generally positive affective responses. While the theme of legitimization carried over into conversations about agency and status at the institutional level, the pursuit of legitimacy on campus inspired a range of positive and negative emotions in respondents. The following section elaborates 
on the professional tensions that arise as librarians navigate relationships with other campus stakeholders.

\section{Status, Agency, and Legitimacy on Campus}

The second research question examined the role of assessment in librarians' agency and status at the institutional level. Several respondents viewed assessment data as a means of achieving higher status and greater agency, while also demonstrating the value of the library. In this way, legitimacy again became a common theme for respondents, who frequently discussed information literacy assessment as a strategic device used to validate both the library and the individual librarian as partners in the educational enterprise.

Respondents indicated that a major reason for conducting information literacy assessment is to demonstrate value to the institution to legitimize the library's purpose on campus. Bre explained that "whether we want to or not, the library has to demonstrate value to their institution so that the institution recognizes that the library is a necessary component." Cora summarized her library's need to demonstrate value as well: "We want to make sure that we're representing the library well... we need to show our worth-do the show-our-worth model, that when people ask 'What do you do in the library?' that you can tell them in concrete terms what that means." In this sense, assessment data serves as a common language, and librarians must speak this language to succeed.

Similarly, many respondents discussed calls for accountability in higher education and how the library legitimizes their role in student learning by answering these calls with assessment data. Zach stated, "There's no doubt that the data we generate and the ability to show that we are being accountable to the university mission is very important on many levels..." while Hannah added that assessment data can help institutional administration "understand the value of the library and the role the library plays in student success...to understand the role of the library in teaching."

In addition to answering calls for accountability as a means of legitimizing the library's role in student learning, many respondents noted that answering such calls is also critical in making the library visible to campus stakeholders. Ruth recognized the importance of this, stating, "I think [accountability] is absolutely necessary for visibility... and proving that what we are doing is aimed at impacting student success on campus." Sadie explained that assessment "shows the rest of the institution that we have a role in student learning," while Tabitha noted that reporting assessment data to the institution is "critical...otherwise it just stays in our little silo and we can only do so much over here."

Conducting assessment was also seen as a way to demonstrate equal status to teaching faculty and to other departments on campus. Zach viewed assessment as a tool to maintain the library's "status in the eyes of the university community" and gather "buy-in" from faculty. On a personal level, Quinn expressed the idea that assessment "puts us more on the same level as a faculty member" while Hannah uses assessment data to "assert my equality or equal standing with my colleagues across departments" and say "hey, I'm a faculty member, too." Similarly, Xander's colleagues "just did a workshop for faculty that was based on the new [ACRL] Framework" and told him "this is how we legitimize ourselves to faculty, that we can do more than just help them find stuff." 23

Information literacy assessment can also help librarians achieve a higher status through a common bond with teaching faculty who are also required to conduct assessment. Alice 
tries "to make that clear that we have the same criteria for assessment that [teaching faculty] have," while Debra implements assessment in information literacy sessions to "let [faculty] know 'this is how I improve my teaching.'"

Visibility to campus stakeholders and a higher status on campus also generated agency for librarians to participate in campus conversations about assessment, a motivation conceptualized as a "seat at the table" by Tabitha. This seat at the table manifested in a variety of ways, including collaboration on assessment initiatives with teaching faculty. Sadie, noticing that students were struggling with an assignment, worked with the instructor to change the assignment; afterward, she "felt really accomplished and satisfied to know that the work we did had an impact on student learning. It was going to change the assignment for next semester, so that felt really good."

At the institutional level, a seat at the table was often described literally as representation on universitywide assessment committees with teaching faculty and administrators. Jonathon is an unofficial member of his campus assessment committee, and because of this he has a "really strong reputation on campus." Sadie also sits on a campus assessment committee and discussed the value of having this seat at the table with institutional leaders: "The assessment director for the university is really thrilled that we have learning outcomes, that we use rubrics, that we have evaluators, so it makes me really happy about it." Thus, these librarians feel empowered and validated by their elevated institutional status in relation to assessment.

Just as the professional teaching identity of librarians is tied to assessment, so is librarians' sense of agency, status, and legitimacy as educators on campus. Zach summed up this connection between assessment and legitimacy on campus, stating that the pressure to assess from higher education "definitely has an impact on [my professional identity], because that involves recognition from higher-ups, and when they see data and when they see someone actively involved, that definitely improves one's standing in their eyes."

While several respondents felt validated and legitimized when using assessment to equalize themselves on campus, others expressed uncertainty in regard to using assessment to address institutional power imbalances. Sadie stated, "I would much rather see the library come from a place of intrinsic motivation and curiosity," while Nina pointed to the "utter minutiae" of listserv conversations about the ACRL Framework for Information Literacy and wondered "how much of [conducting assessment] is wanting to be better at my job and how much of it is like this internal trying to confer legitimacy on our jobs in a world that doesn't really value us and doesn't really think we do anything more than...shuffle books around."

Indeed, other respondents expressed frustration in their perception that librarianship is often undervalued or misunderstood; Xander felt that institutional pressure to assess information literacy was "offensive, in that [we] feel like it may be sort of devaluing our profession." Hannah questioned the need to provide assessment data to an institution that does not understand the work of librarians: "How dare you think you can come in here and tell us what we do wrong when you have no understanding of what our industry is?" There is a sense in these comments that the expectation to assess comes from external forces in higher education, forces that fail to grasp or appreciate the professional context of librarianship.

\section{Challenges to Using Information Literacy Assessment to Confer Legitimacy} The third and final research question explored challenges experienced by librarians in conducting assessment. Conversations about the role of assessment in librarians' professional identity 
and the role of assessment in librarians' sense of agency and status on campus indicated that a key motivation for conducting information literacy assessment is to legitimize themselves as educators. At the institutional level, this legitimization allows librarians to gain a higher status on campus and thus affect agency outside the library. To that end, librarians identified a number of challenges to conducting information literacy assessment that, in turn, had an impact on their ability to grow in their professional identity as educators and gain status and agency on campus. Namely, respondents indicated that a lack of resources, the utility of assessment data on campus, and organizational tensions had a negative impact upon their ability to use information literacy assessment data to legitimize themselves as educators.

\section{Resources}

Much of the conversation surrounding challenges to information literacy assessment was resource-related-more specifically, a lack of appropriate resources for conducting assessment. A common concern among many respondents was that they lacked the skill set to reliably and meaningfully assess student learning and did not have the time or staffing levels necessary to improve their skill set. Without appropriate resources and skills for conducting assessment, their use of assessment data to improve themselves as educators and legitimize their status on campus became a moot point.

Cora highlighted the mixed signals she receives at her institution, where librarians are encouraged to conduct assessment but have not "been given the training or the resources or the time to actually make it happen." Fiona faced a similar challenge, stating that she did not know "how to do the assessment research." Several respondents also lacked adequate resources in regard to staffing. For example, Olivia's library just did not have the "people to get some of this done." Even respondents who had the skillset and the staff to conduct appropriate assessment faced a different challenge: not knowing how to use the data once it was obtained. Iris is in this situation and explained, "I just think many librarians are not well-schooled in how to use those numbers to their main advantage."

Several respondents also expressed concerns that their primary resource for guidance in information literacy assessment, the ACRL Framework, is not an appropriate tool for conducting meaningful assessment. Gwen stated, "When we had to switch over from the Standards to the Framework, that threw the library world into chaos. People who were assessing were saying, 'How are we going to measure this?'" while Bre described her own colleagues' negative feelings: "I think there's still some discontent from some librarians about how do we assess with the Framework." Fiona also described resentment among her colleagues and felt discouraged by listserv comments like, "There's no way...that I'm going to integrate the Framework because it's impossible to assess." Based on these responses, it is evident that many instruction librarians are still working through the implications of the Framework and its potential role in information literacy assessment, a process that can be confusing and frustrating.

An interesting nuance to this conversation was that some felt resource-related anxiety was not an emotion exclusively tied to librarianship. Hannah stated, "I think higher ed is desperately trying to develop metrics to get at the whole picture, but they're all just incomplete...I don't think anyone has figured out a way to represent the context and the human factor in our higher ed assessment." Sadie echoed this sentiment, sharing, "I think there's a lot of anxiety around assessment in higher education for a lot of different stakeholders." 


\section{The Utility of Information Literacy Assessment Data}

Another challenge to using information literacy assessment data to confer legitimacy was the actual utility of the data itself; namely, the meaningfulness of the data both in terms of their value for personal practice and professional identity, as well as for improving status and agency within the library and institution. A number of respondents expressed feelings of fear, mistrust, and uncertainty as to how, or if, information literacy data would be used by campus stakeholders in making strategic decisions. Eleanor referenced this fear of being held accountable for things that either "you have no control over" or "you maybe can't realistically measure." Cora stated that "just knowing what questions might be meaningful" posed a consistent challenge with assessment, and the lack of meaningful assessment data could potentially have a negative impact on librarians' legitimacy on campus if they are unable to demonstrate their accountability.

Respondents were also concerned with the variety of ways someone could construe objective assessment data in a subjective way. Eleanor reported that "95\% of students say [library instruction] is helpful to them" which, to her, was an "important" indicator of status and legitimacy, both personally and for purposes of marketing library services. For administrators, though, this data was "meaningless." Iris also related to this issue, sharing that "numbers can tell different stories the way people can interpret them." Thus, assessment data that feels legitimizing to librarians might not legitimize their work as educators in the eyes of other campus stakeholders, who may misinterpret the data.

A final concern of respondents regarding the utility of their assessment data was not that the data would be seen as meaningless or that it would be misconstrued, but that the assessment data would simply not be used, or even reviewed, by institutional higher-ups. Yvonne stated, "I've never seen how or if that data is actually incorporated [by the institution]," while Olivia conjectured that the data was "probably...just shoved right into the trash can. We really have no idea." For these respondents, the assessment process can seem mysterious or even trivial due to the ambiguity surrounding the institution's use of the data.

\section{Organizational Tensions}

Respondents discussed several organizational tensions that hindered the utility of assessment data in improving their legitimacy as educators on campus. Perhaps the most common challenge identified by respondents in using assessment to increase librarians' legitimacy was that they were inherently viewed as "lesser than" by the institution in such a way that their use of assessment did not matter in their efforts to increase their legitimacy. Debra explained that there is a "tension in higher education that libraries are lesser and librarians aren't real faculty...we're treated differently, 'staffulty' is the way we refer to it." Alice also spoke to this feeling of marginalization, stating, "the library is separate from the rest of the university... you know you're faculty, but you're not real faculty." Overall, respondents reported that, when they were not seen as teachers, it indicated a sense of inequity on campus that many felt rendered their information literacy assessment data ineffectual.

Other respondents did not necessarily feel that they are treated as "lesser than" by the institution, but instead that there is simply a general ignorance on campus about the role of librarians. Iris received a comment from a patron who said, "The public library has all of these databases, too. Why do we even need the campus library?" Even with the use of assessment data to show student learning, a lack of understanding of librarians' role as educators impacts 
their ability to achieve a higher status on campus, as acknowledged by Tabitha: "Traditionally, there's always that stereotype...we're just over here with our hair in buns...we've got books, that's what we do."

Echoing this feeling of being misunderstood by the institution and campus stakeholders, a number of respondents indicated issues in working with teaching faculty who bring their classes to the library for instruction. While librarians use assessment as a means of achieving a higher status on par with teaching faculty, they are still beholden to teaching faculty when asking for class time to assess. Alice noted that teaching faculty "don't understand necessarily that the library is part of that broader world and we need those same tools to work with." This challenge, referred to as a lack of "buy-in" by several respondents including Lauren, Yvonne, and Zach, hinders librarians from obtaining the data they need to assert their value on campus.

Interestingly, one final organizational tension acknowledged by respondents was that by playing into the calls for assessment by institutional administrators, librarians end up curtailing their creativity and agency as educators and therefore their efficacy-that is, there is a trade-off between higher status on campus and creativity with regard to teaching and learning. Pointing to a kind of artificial and stifling uniformity in teaching practice, Quinn noted that "assessment makes you... a lot less creative, and you kind of end up teaching to the test." Thus, for some respondents, while status on campus was potentially increased, professional agency and autonomy may be at risk when librarians are treated more like teaching faculty.

\section{Discussion and Recommendations}

The purpose of this study was to explore academic instruction librarians' perceptions of and experiences with information literacy assessment, focusing in particular on the relationship between assessment and professional identity, agency, and status. By examining the nuances of shared experiences through phenomenological interviews, the study also provides insight into the affective dimensions of assessment practice - that is, the emotional highs and lows librarians experience as they navigate various professional and organizational tensions in the course of their work. The findings reaffirm much of the previous research on the teaching identity in librarianship, as well as the significant influence of campus power relations on library instruction, including the influence of these relations on the sometimes conflicting emotions librarians experience in carrying out their instructional responsibilities. ${ }^{24} \mathrm{At}$ the same time, this study expands upon the existing literature by demonstrating the centrality of assessment to the librarian teaching identity and highlighting the role of assessment in legitimizing library instruction, advancing the agency and status of librarians on campus, and communicating the value of information literacy through a shared language across the institution. In this sense, assessment is the means by which librarians influence teaching and learning activities and achieve power in their respective organizations. In other words, assessment gives them a proverbial seat at the table. However, as librarians seek to make meaning of their experiences with assessment in their individual contexts, they encounter a variety of challenges and tensions that complicate their relationship with the assessment process.

The librarians in this study, in line with previous research, view teaching as an integral part of their professional identity. ${ }^{25}$ For most participants, assessment is a fundamental aspect of this identity that serves to legitimize librarians as true teachers in their own eyes and potentially in the eyes of their institutions. In both explicit and implicit ways, librarians refer to legitimacy as a key motivation for participating in assessment, even as the pursuit of legiti- 
macy inspires both positive and negative affective responses. Echoing the findings of Julien and Pecoskie, respondents in this study experience a power imbalance between themselves and teaching faculty, particularly in regard to agency and status. ${ }^{26}$ While most librarians are excited about teaching and often enthusiastic about the productive possibilities of assessment work, this power imbalance in relation to teaching faculty may elicit feelings of frustration and uncertainty, calling into question the very legitimacy that librarians strive to attain. These findings suggest that the professional identity crisis that $\mathrm{O}^{\prime} \mathrm{C}$ Connor points to as a major factor in the early information literacy movement continues to linger in librarianship today. ${ }^{27}$ While assessment provides an opportunity to bring librarians closer to the status of traditional teaching faculty, many librarians still feel marginalized and/or misunderstood on campus and may lack the necessary resources and training to improve their status, despite a well-established educational mission. Thus, instruction librarians' relationship with assessment remains dynamic and, following Drabinski, reveals the professional tensions of particular moments in time. ${ }^{28}$ In this current moment, when assessment has become such a prominent fixture of the higher education landscape in the United States, it follows that instruction librarians would use assessment to assert and legitimize their status as equal partners in education.

While this study highlights how many librarians use assessment to legitimize themselves as educators, it also delineates the challenges that librarians face in conducting assessment, challenges that might be characterized as threats to achieving full legitimization and status on par with teaching faculty. Previous studies have identified similar challenges associated with information literacy instruction and assessment. ${ }^{29}$ This study suggests that these challenges remain persistent concerns in the profession: librarians have limited resources for systematic assessment, question the utility of assessment data, and experience organizational tensions and power struggles that hinder their assessment efforts. Perhaps the most important step librarians can take in addressing these challenges is to be transparent in communication with campus stakeholders. Several respondents felt misunderstood or undervalued by campus stakeholders, but some acknowledged the benefits of being open with teaching faculty about their requirement to conduct assessment, echoing Julien and Pecoskie's finding on the importance of such relationships. ${ }^{30}$ Similarly, librarians should encourage transparency from their library administration about what data is needed and how it will be used by the library. Many respondents stated that they are unsure how assessment data is used by the institution, so librarians should seek administrative support in addressing these uncertainties as well. Finally, librarians must be proactive in their assessment efforts. Lack of training was discussed frequently by respondents, and not much can be done about a lack of funding or time for indepth training. However, librarians can take small steps toward improving their assessment skills, like looking to the recent literature on successful assessment programs, ${ }^{31}$ seeking out webinars to learn basic assessment skills, or reaching out to local colleagues for support and guidance. This will be especially important for those librarians interested in incorporating the ACRL Framework into their assessment activities. Librarians can also be proactive in pursuing their own seats at the table on campus assessment committees to advocate for the library's role in student learning.

The authors recognize the limitations of the present study. A majority of participants identified as white, heterosexual females; conversations about status and agency within an educational institution could be vastly different when discussing such issues with members of other demographic groups. Another limitation is the generalization across institution types, 
as respondents represented community colleges, private liberal arts colleges, and large public universities. Future research could focus on particular academic institution types to address the generalizations inherent in this study. One final limitation is that all three authors are instruction librarians who have their own experiences with and perceptions of information literacy assessment. While the authors sought to remain objective when interviewing respondents and identifying themes within the data, it is possible that their backgrounds and experiences could have subconsciously influenced respondents and results.

This study provides an in-depth exploration of the work of academic instruction librarians in regard to assessment of information literacy instruction. Future research should continue to investigate academic instruction librarians' experiences with and perceptions of various aspects of instruction and assessment, including further exploration into themes of identity, agency, status, and legitimacy. Such studies may provide additional insights not only into information literacy practice on the ground level but also into the operations of power as experienced by librarians in the current professional context. 


\section{APPENDIX. Interview Guide Professional Variables}

What type of librarian would you classify yourself as?

How long have you been employed as a librarian?

What did you major in as an undergraduate student?

Where did you obtain your undergraduate degree?

Where did you obtain your Master of Library Science degree?

Are there any other degrees or training you have?

Do you have any specific training in assessment?

As a part of your job duties, what percentage would you assign to your responsibilities related to information literacy instruction?

How many classes do you teach in an academic year?

As a part of your job duties, how often do you interact with students? [1-10, 10 being high interaction]

As a part of your job duties, how often do you interact with faculty? [1-10, 10 being high interaction]

Which description is the best fit for your institution type? (Doctoral University, Master's University/College, Baccalaureate College, Associate's College, Other: Please Describe.)

Is your institution public or private?

What is the size of your institution?

- $0-5,000$ students

- 5,001-10,000 students

- $10,001-15,000$ students

- 15,001-20,000 students

- 20,001-25,000 students

- 25,001-30,000 students

- 30,001-35,000 students

- 35,001-40,000 students

- More than 40,000 students

\section{Librarians and Assessment: Personal/General}

What do you think the role of assessment is in library instruction?

Do you do assessment for library instruction?

What kinds of assessment do you do for library instruction?

Why do you do assessment for library instruction? (Personal practice, mandated by library or university administration, pressure from profession, combination, other?)

What do you think about doing assessment for library instruction?

How do you feel about doing assessment for library instruction?

Are there any challenges you have in doing assessment for library instruction?

How have you responded to these challenges?

How do these things we've been talking about affect how you perform your job responsibilities?

How do these things we've been talking about affect your professional identity? 


\section{Librarians and Assessment: Calls from Library Administration}

How would you characterize the conversation about assessment at your library?

Are you required to assess library instruction as a part of your job duties by library administration?

Do you report the assessment data to anyone at your library? (Recommended, mandated, other?)

\section{If yes, ask the following questions:}

What do you think about reporting assessment data to library administration?

How do you feel about reporting assessment data to library administration?

Are there any challenges to reporting assessment data to library administration?

How have you responded to these challenges in reporting assessment data to library administration?

How do these things we've been talking about affect how you perform your job responsibilities?

How do these things we've been talking about affect your professional identity?

\section{If no, ask the following questions:}

What do you think about not reporting assessment data to library administration?

How do you feel about not reporting assessment data to library administration?

Are there challenges associated with not reporting assessment data to the library administration?

How have you responded to these challenges associated with not reporting assessment data to the library administration?

How do these things we've been talking about affect how you perform your job responsibilities?

How do these things we've been talking about affect your professional identity?

\section{Librarians and Assessment: Calls from the Profession}

How would you characterize the professional conversation about assessment?

Do you see your library fitting into this professional conversation? How?

What do you think about the professional conversation surrounding assessment?

How do you feel about the professional conversation surrounding assessment?

What are any challenges you have about fitting into the professional conversation surrounding assessment?

How have you responded to the professional conversation surrounding assessment?

How do these things we've been talking about affect how you perform your job duties?

How do these things we've been talking about affect your professional identity?

\section{Librarians and Assessment: Call from Higher Education}

How would you characterize the conversation about assessment in higher education?

What are your thoughts on calls for accountability in higher education?

Do you see the library fitting into the call for accountability? How?

What do you think about the library fitting into the call for accountability? 
How do you feel about the library fitting into the call for accountability?

What are challenges to fitting the library into the call for accountability?

How have you responded to calls from higher education to demonstrate the library's accountability?

How do these things we've been talking about affect how you perform your job duties?

How do these things we've been talking about affect your professional identity?

How have you or your library responded to calls for accountability at your institution?

Do you report your assessment data to anyone at the institution? (If not, is someone at your library reporting it to the institution?)

If yes, ask the following questions:

If so, do you know how the data are used by the institution?

What do you think about reporting assessment data to the institution?

How do you feel about reporting assessment data to the institution?

What are challenges associated with reporting assessment data to the institution?

How do these things we've been talking about affect how you perform your job duties?

How do these things we've been talking about affect your professional identity?

\section{If no, ask the following questions:}

What do you think about not reporting assessment data to the institution?

How do you feel about not reporting assessment data to the institution?

What are challenges associated with not reporting assessment data to the institution?

How do these things we've been talking about affect how you perform your job duties?

How do these things we've been talking about affect your professional identity?

\section{Demographic Variables}

What is your age?

What is your sex?

How would you define your race or ethnicity?

How would you define your sexual orientation?

How would you define your relationship status?

\section{Notes}

1. Thomas P. Mackey and Trudi E. Jacobson, Collaborative Information Literacy Assessments: Strategies for Evaluating Teaching and Learning (New York, NY: Neal-Schuman, 2010); Teresa Y. Neely, Information Literacy Assessment: Standards-Based Tools and Assignments (Chicago, IL: American Library Association, 2006); Carolyn J. Radcliff, Mary Lee Jensen, Joseph A. Salem Jr., Kenneth J. Burhanna, and Julie A. Gedeon, A Practical Guide to Information Literacy Assessment for Academic Librarians (Westport, CT: Libraries Unlimited, 2007); Dorothy Warner, A Disciplinary Blueprint for the Assessment of Information Literacy (Westport, CT: Libraries Unlimited, 2008).

2. Amanda Albert, "Communicating Library Value: The Missing Piece of the Assessment Puzzle," Journal of Academic Librarianship 40, no. 6 (2014): 634-37; Association of College and Research Libraries, "Academic Library Contributions to Student Success: Documented Practices from the Field" (ACRL, 2015), available online at www.ala.org/acrl/sites/ala.org.acrl/files/content/issues/value/contributions_report.pdf [accessed 12 September 2018]; Joseph R. Matthews, "Assessing Library Contributions to University Outcomes: The Need for Individual Student Level Data," Library Management 33, no. 6/7 (2012): 389-402; Megan Oakleaf, "The Value of Academic Libraries: A Comprehensive Research Review and Report" (ACRL, 2010); available online at www.ala.org/acrl/ sites/ala.org.acrl/files/content/issues/value/val_report.pdf [accessed 12 September 2018]; Megan Oakleaf, "The Information Literacy Instruction Assessment Cycle: A Guide for Increasing Student Learning and Improving Librarian Instructional Skills," Journal of Documentation 65, no. 4 (2009): 539-60; Devin Savage, Pattie Piotrowski, 
and Lisa Massengale, "Academic Librarians Engage with Assessment Methods and Tools," portal: Libraries $\mathcal{E}$ the Academy 17, no. 2 (2017): 403-17.

3. Allison Erlinger, "Outcomes Assessment in Undergraduate Information Literacy Instruction: A Systematic Review," College \& Research Libraries 79, no. 4 (2018): 442-79.

4. Savage, Piotrowski, and Massengale, "Academic Librarians Engage with Assessment Methods and Tools."

5. Megan Oakleaf and Lisa Janicke Hinchliffe, "Assessment Cycle or Circular File: Do Academic Librarians Use Information Literacy Assessment Data?" (paper presented at the Library Assessment Conference, Seattle, WA, 2008), available online at https://papers.ssrn.com/sol3/papers.cfm?abstract_id=2597894 [accessed 12 September 2018].

6. Karen Sobel and Cassidy R. Sugimoto, "Assessment of Learning during Library Instruction: Practices, Prevalence, and Preparation," Journal of Academic Librarianship 38, no. 4 (2012): 191-204.

7. Heidi Julien, Melissa Gross, and Don Latham, "Survey of Information Literacy Instructional Practices in U.S. Academic Libraries," College \& Research Libraries 79, no. 2 (2018): 189.

8. Julien, Gross, and Latham, "Survey of Information Literacy Instructional Practices in U.S. Academic Libraries," 191.

9. Barry W. Cull, "Voices in the Wilderness: A Report on Academic Information Literacy Instruction in Atlantic Canada," Canadian Journal of Information and Library Science 29, no. 1 (2005): 1-26; Heidi Julien, "Information Literacy Instruction in Canadian Academic Libraries: Longitudinal Trends and International Comparisons," College E Research Libraries 61, no. 6 (2000): 510-23; Heidi Julien and Stuart Boon, "From the Front Line: Information Literacy Instruction in Canadian Academic Libraries," Reference Services Review 30, no. 2 (2002): 143-49.

10. Julien, "Information Literacy Instruction in Canadian Academic Libraries"; Cull, "Voices in the Wilderness," 5.

11. Heidi Julien and Shelagh K. Genuis, “Librarians' Experiences of the Teaching Role: A National Survey of Librarians," Library and Information Science Research 33, no. 2 (2011): 107.

12. Scott Walter, "Librarians as Teachers: A Qualitative Inquiry into Professional Identity," College and Research Libraries 69, no. 1 (2008): 51-70.

13. Celene Seymour, "Ethnographic Study of Information Literacy Librarians' Work Experience: A Report from Two States," in Transforming Information Literacy Programs: Intersecting Frontiers of Self, Library Culture, and Campus Community, eds. Carroll Wetzel Wilkinson and Courtney Bruch (Chicago, IL: Association of College and Research Libraries, 2012): 45-71.

14. Heidi Julien and Jen J.L. Pecoskie, "Librarians' Experiences of the Teaching Role: Grounded in Campus Relationships," Library and Information Science Research 31, no. 3 (2009): 149-54.

15. Lisa O'Connor, "Information Literacy as Professional Legitimation: The Quest for a New Jurisdiction," Library Review 58, no. 7 (2009): 496.

16. O'Connor, "Information Literacy as Professional Legitimation," 503.

17. Robert Zai III, “Neither Fish nor Fowl: A Role Theory Approach to Librarians Teaching," Journal of Library Administration 55, no. 1 (2015): 1-23.

18. Emily Drabinski, "Becoming Librarians, Becoming Teachers: Kairos and Professional Identity," Canadian Journal of Information and Library Science 40, no. 1 (2016): 27-36.

19. Irving Seidman, Interviewing as Qualitative Research: A Guide for Researchers in Education and the Social Sciences, 4th ed. (New York, NY: Teachers College Press, 2013).

20. Rick L. Fought, "Accepting the Challenge: What Academic Health Sciences Library Directors Do to Become Effective Leaders," Journal of the Medical Library Association 106, no. 2 (2018): 220.

21. Andrew A. Beveridge, Susan Weber, and Sydney Beveridge, "Librarians in the United States from 18802009," (Oxford University Press Blog, 2015), available online at https://blog.oup.com/2011/06/librarian-census [accessed 12 September 2018].

22. John Lofland, David A. Snow, Leon Anderson, and Lyn H. Lofland, Analyzing Social Settings: A Guide to Qualitative Observation and Analysis, 4th ed. (Belmont, CA: Wadsworth, 2006).

23. Association of College and Research Libraries, "Framework for Information Literacy for Higher Education" (Jan. 11, 2016), available online at www.ala.org/acrl/standards/ilframework [accessed 3 January 2019].

24. Heidi Julien and Shelagh K. Genuis, "Emotional Labour in Librarians' Instructional Work," Journal of Documentation 65, no. 6 (2009): 926-37.

25. Cull, "Voices in the Wilderness," 1-26; Julien and Genuis, "Librarians' Experiences of the Teaching Role," 103-11; Walter, "Librarians as Teachers," 51-70.

26. Julien and Pecoskie, "Librarians' Experiences of the Teaching Role," 149-54.

27. O'Connor, "Information Literacy as Professional Legitimation," 493-508.

28. Drabinski, "Becoming Librarians, Becoming Teachers: Kairos and Professional Identity," 27-36. 
29. Oakleaf and Hinchliffe, "Assessment Cycle or Circular File"; Julien, Gross, and Latham, "Survey of Information Literacy Instructional Practices in U.S. Academic Libraries," 179-99; Cull, "Voices in the Wilderness," 1-26; Julien, "Information Literacy Instruction in Canadian Academic Libraries," 510-23; Julien and Boon, "From the Front Line: Information Literacy Instruction in Canadian Academic Libraries," 143-49.

30. Julien and Pecoskie, "Librarians' Experiences of the Teaching Role," 149-54.

31. Erlinger, "Outcomes Assessment in Undergraduate Information Literacy Instruction," 442-79; Savage, Piotrowski, and Massengale, "Academic Librarians Engage with Assessment Methods and Tools," 403-17. 